\title{
Research on the Reform Orientation of College Ideological and Political Course System under Background of Chinese Dream and New Normal
}

\author{
Jiaqian Zhang \\ Department of Social Sciences, Binzhou Polytechnic, \\ Shandong,256600,China
}

\begin{abstract}
In this paper, we conduct research on the reform orientation of the college ideological and the political course system under background of the Chinese dream and new normal. The complex phenomenon of ideological and political education to our ideological and political education essence, grasp the law of ideological and political education to increase the difficulty. As an ideological and the political educators, it is necessary to continuously enhance the ability of dealing with the complex problems that is good at through the complex phenomenon of the ideological and political education, understanding and grasping the essence of the ideological and political education. We combine the primary analysis of the Chinese dream and new normal to form the optimal education paradigm for the college ideological and the political course system that is necessary.
\end{abstract}

Keywords- Reform Orientation, Ideological and Political, Course System, New Normal, Dream.

\section{Introduction}

With the deepening of education reform, the teaching ideas are changing, guide teacher from imparter of knowledge to knowledge, from mechanically teaching materials to personalized, practical, creative use of teaching materials, teaching from the focus on the student learning evaluation result for the purpose to cultivate the students' good learning method, cultivating students' innovative ability for the education ultimate goal. In terms of teaching reform in colleges and universities that is the main link of teaching concept, teaching mode and teaching method [1-3].

The teaching research into the specific teaching thoughts, teaching ideas, into the teaching decision scheme, into curriculum, textbooks, teaching software and chemical products, such as technology into teaching behavior and teaching practice workers. According to different ways into practice to research the prototype and the degree of utilization, teaching research results can be converted into practice is divided into three types. (1) The migration of applied. Teaching main body can be through the flexible use of teaching research results reasonably in different disciplines and areas as use results in teaching practice guidance and service. This transformation in practice, there exist certain screening and high flexibility that is a kind of very good form. (2) Development of translational. This transformation type is practitioners in the process of application of the teaching research as research results of the original teaching research again, make an adjustment on the basis of former research results, make the original work of deepening and the development and make it more perfect. (3) Direct conversion type. This transformation type must follow the original research teaching reform research concrete operation procedures and related regulations, do not make any changes, the teaching research results directly in the same subject within a certain scope of application. According to their own actual conditions and teaching in practice 
into their own knowledge system and scientific ideas, to update and improve the former research results, finally it is concluded that a set of suitable teaching methods and means, and use and implement as the teaching research results to maximize [4].

Phenomenon and the essence is a pair of categories of the materialist dialectics, both opposite and unified. Although know the mission is to reveal the nature of things, but the way to know and only from the phenomenon of things, to grasp the essence through the phenomena. Similarly, to grasp the essence of ideological and political education, also must study the phenomenon of the ideological and political education. The essence of the so-called ideological and the political education, namely the fundamental nature of ideological and political education, it is the internal link of ideological and the political education, ideological and political education is intrinsic, relatively stable, it is the existence and general development of ideological and political education plays a decisive role. The objectivity of ideological and political education phenomenon is by result of the above two factors interaction, ignoring any one aspect, the ideological and political education phenomenon won't really happen [5].

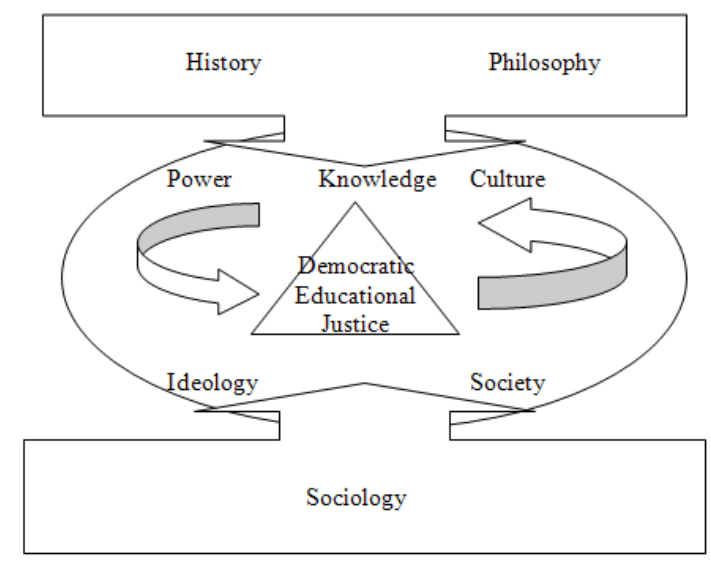

Figure 1. The Principles of the Ideological and Political Course
In this paper, we conduct research on the reform orientation of the college ideological and political course system under background of Chinese dream and new normal. Phenomenon of ideological and political education has the characteristics of objectivity, universality, complexity. Phenomenon of ideological and political education from the basic point of the objectivity, not only it is the objective requirement of the ideas of ruling class rule is also the objective requirement of the people's spiritual needs. Phenomenon of ideological and political education from the point of universality, performance in different countries and the social ideological and political education purpose that is consistency, ideological and political education content is identity, the respect such as ideological and political education method has many helps for from the perspective of complexity, the ideological and political education phenomenon in the illusion, particularity, diversity, etc.

\section{Our Proposed Methodology and Perspective}

The Features of New Normal. New normal this concept was first made in 2009 by the United States pacific investment management company, to describe the crisis after the European and the American developed economy no longer back to less than before, the main meaning is: low growth and high unemployment will continue for long; corporate profits, return on capital will be reduced. In macro field is often used to describe the crisis after the economy's recovery was slow and difficult process. But others point out that economic development has the certain regularity, its performance also has certain periodicity, after arrival in the new stage of the economic characteristic of this stage should be accepted and adaptation. A potential future China's macro economy the trend of economic growth is slowing at the same time also has the positive factors in the medium term beyond the new normal. Under the new normal, although China's 
economic growth slowed, the increment is considerable.

The challenges we should meet with in the later years could be summarized as the follows. (1) Excess production capacity. Overcapacity is a normal phenomenon in market economy. However, the current of excess production capacity in China is serious, never use the general principle of market economy be explained, among them, the institutional reasons. Direct cause of the excess capacity, of course, it is the enterprise blind expansion, however, without behind expansion of local government impulses, corporate mesh expansion never form the climate. (2) The debt risk. As to achieve the target of deleveraging, we must be determined to twist to indirect financing, financing structure, develop multi-level capital market. In addition, the further reform of the state-owned economy, control the soft budget constraint under the tendency of high debt, control the investment behavior of the government at all levels, that control its financing activities, etc., are the countermeasures to leverage fundamental system in China. In the investigation of the country's overall debt levels at the same time, government debt, especially local government debt long-term change tendency, especially worthy of attention. (3) The transformation of urbanization. Urbanization has been one of China's economic development momentums. In the recent years, with the traditional process nearing completion of industrialization, urbanization has been given more to keep the Chinese economy long-term growth in the future the anchorage of the main engine. For decades, however, the practice of traditional urbanization, as also accumulated a large number of deep-seated contradictions, when the urbanization become the main engine of economic development, and thus on deeper complex associated with the national economy in various fields, these contradictions constitute urbanization new challenge under the new norm.

The Connotation of the Chinese Dream. Think more, the night somewhat dream. The
Chinese dream as a great dream, and dream is not a castle in the air, but the Chinese nation and the Chinese people's great ideal, where the public opinion is, the spirit of place. Dreams with people to dream, the pursuit of beauty or states, dream is unrealistic, cannot be put into action, fantasy is not possible. Ideal is based on the reality of prospective prediction, a set of strategic ideas and beliefs, etc. The Chinese dream is great dreams can become a reality, it is worth persevering pursuit of lofty ideals, guided by the Marxism based on general basis, carrying addition, promote the general layout, predictable and expectation about Chinese characteristic socialist economy, politics, culture, society and ecological civilization construction and to the long-term goal of man's all-round development and good vision.

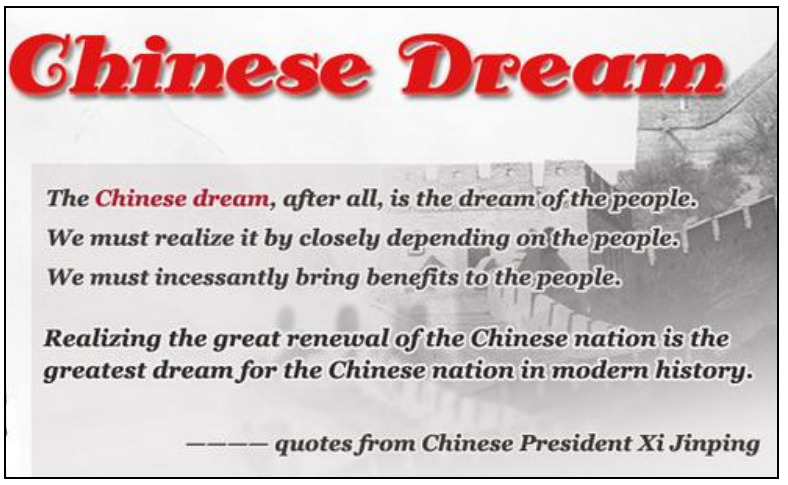

Figure 2. The Connotation of the Chinese Dream

"Chinese dream" is to realize national rich and strong, rejuvenation, people's happiness. To realize the great rejuvenation of the Chinese nation is the one hundred dreams of countless Chinese sons and daughters. Than at any other time in history, we are closer to the goal of national revival is all the more confidence and ability to achieve your dream. But to achieve the great cause, need generation after generation of Chinese people joint effort, unremitting struggle, to every generation of the youth to shoulder their own historical mission, different age of youth facing different historical subject, bear the different mission. The Chinese dream reflects the unity of the resultant force and stress. From the 
country as a whole and collective social level, China's dream is a national, is the soul of a spirit of power, and rejuvenating the country, condensed the minds of the Chinese people, and consolidate the common social ideological basis, strengthened national parties, groups, all nationalities, all classes, people from all walks of life of the integration of thought and behavior that is advantageous to the coagulation hearts meet force. Citizens from the individual level, the Chinese dream is the dream of every Chinese, set up the strong spiritual pillar is helpful to arouse enthusiasm of individual citizens, initiative and creativity to make public individual character, stimulate vitality and positive energy.

The Reform Orientation of the College Education. In order to make the basic higher education teaching better adapt to China's reform and opening up and socialist modernization construction on the talent requirements, adapt to the socialist market economic system's need for talents training and adapt to the new trend in the development of science and technology, higher education has accelerated the pace of reform, intensify the reform forms and the achieved gratifying results. But from the current situation of the higher education teaching reform in our country there are still some problems, mainly displays in: the task of reform of higher education teaching difficulty, the complexity of the education teaching reform process, the education teaching reform organization scattered features, etc. Higher education teaching reform has a long way while it is a systematic project, involving every aspect of the education teaching content, involving the whole society, the country the education administrative departments at all levels and departments within the institutions of higher learning. At the same time due to a longer periodic education teaching and related investment and inadequate people, restricts the education teaching reform achievement of the promotion and application. The above view, higher education teaching reform is necessary to strengthen management. How to improve college students' ability of self-management in the colleges and universities is not only a theoretical problem, but is a promote quality education, improve the quality of education, which is related to the practical problem of the quality of universities which is listed as the following aspects [6-7].

- Schools and departments to create conditions for student self-management, to build platform, built with class, students, community, students, party organization, network and so on more than one of the university students' self-management organization system, and establish and improve student self-management organization system operation mechanism, core formation dominated by teachers, students as the main body of the hierarchy management echelon.

- Humanism education idea to cultivate all-round development of human education, emphasis on education should go deep into the student's life, body and mind, learning all aspects, such as that student is the main body, any management system of the power and can suppress the development of students as the main body, emphasizes the initiative of self-management.

- Student management workers, while letting students' self-management, to help the students improve themselves management rules of basic construction, formulate rational and effective evaluation system and standard, and carry on strict examination management and reasonable value evaluation and timely monitoring, to achieve the goal of the overall goals and points to the factors of self-management goals to encourage them.

The Ideological and the Political Course System. What is the nature of ideological and political education, it is problem in the study of 
ideological and political education as the study of this problem has important theoretical significance and practical significance since the ideological and political education to produce, scholars from different angles on the essence of the ideological and political education on the thorough and comprehensive discussion that formed a variety of views.

Establish correct methodology, relying on the scientific method to solve our faces many problems in the ideological and political education practice that is the ideological and political education theory researchers and practical workers basic quality requirements. Early at the beginning of ideological and political education discipline to create, senior economist will methodology of the ideological and the political education as an important theoretical category and subject areas as part of the ideological and political education discipline theory. As the construction and development of ideological and political education disciplines and specialties, the study of the theory of the ideological and political education methods and methodology discipline construction has made great progress.

In combination with characteristics of new generation college students audience as well as the starting point and the source of ideological and the political courses, from the new generation college students lead audience's psychology, ideological and political course system, content and ideological and political course teaching methods from three aspects of reform. (1) Combined with characteristics of the new generation college student audience rich classroom teaching content, improve pertinence and effectiveness of classroom teaching. To continue to increase the pertinence of the ideological and political course, the course content in the form of a project or case is presented to students, teaching content should be close to the new generation of college life and actual needs, enhance the pertinence of curriculum design, of the events at home and abroad into the reality curriculum content, the simple realization of the content. (2) In the process of ideological and political course teaching, also need to continuously strengthen the new generation of the college students' ideal faith education, guide the gradually sets up the lofty ideal, with Marxism as the platform, resist corruption by decadent ideas culture, develops the new generation of the college students political vision, firm the ideal faith. (3) Combined with the characteristics of the new generation college students audience reform ideological and political course teaching ways and methods, improve the flexibility and the diversity of courses. Combined with new generation of college students' participation, to make the case teaching method to guide the case discussion to accept knowledge, team's cooperative and exploratory implementation team, in the case teaching, to combine the new generation of college students' time background, the choice can reflect the living environment of the typical cases, and proper treatment, through the case discussion and thinking to improve their learning interest in ideological and political course system.

\section{Conclusion}

In this paper, we conduct research on the reform orientation of the college ideological and the political course system under background of the Chinese dream and new normal. The problem of development of ideological and political education method as a focal point of ideological and political education research methodology is a very urgent task. Development of ideological and the political education methods is an important content of ideological and political education research methodology, it is rooted in the ideological and political education practice, focus on the development of the theory of the ideological and political education methods and enhance the effectiveness of the ideological and the political education. Therefore, in this paper, we conduct the corresponding research to 
provide the new perspective of the education reform.

\section{References}

[1] Wang, Zheng. "The Chinese dream: concept and context." Journal of Chinese Political Science 19.1 (2014): 1-13.

[2] Zhao, Kejin, and Xin Gao. "Pursuing the Chinese Dream: Institutional Changes of Chinese Diplomacy under President Xi Jinping." China Quarterly of International Strategic Studies 1.01 (2015): 35-57.

[3] Mattke, Soeren, et al. The Role of Health Care Transformation for the Chinese Dream. Rand Corporation, 2014.

[4] Guoping, Zeng, and Wei Feng. "The Realization of the Great "Chinese Dream" and the Establishment of Community
Socialist Core Values." Public Administration \& Law 1 (2015): 4.

[5] Dongliang, Z. H. A. N. G. "A Review on the Study of the Ideological and Political Theory Course Teachers' Personality Charm in College." Journal of Chengdu University of Technology (Social Sciences) 6 (2014): 001.

[6] Siyu, L. I. "Thoughts on Promoting College Ideological and Political Education with Micro-blog [J]." Journal of Chongqing University of Posts and Telecommunications (Social Science Edition) 4 (2012): 018.

[7] Cabrera, Nolan León. "Exposing Whiteness in higher education: White male college students minimizing racism, claiming victimization, and recreating White supremacy." Race Ethnicity and Education 17.1 (2014): 30-55. 